\title{
The Modernity of Naga Village Community: Social Change Study through Visual Media Analisys
}

\author{
Agus Setiawan \\ Visual Communication Design Study Program, Faculty of Arts and Literature \\ Setiabudhi 193 Bandung West Java Indonesia \\ agussfiss@gmail.com
}

\begin{abstract}
Looking at the cultural area landscape, Tatar Sunda certainly inherited different rich culture then other regions. It not only inherited tangible cultural wealth but also intangible. However, in the midst of an increasingly advanced civilization, now the Sundanese cultural heritage has changed its existence. Functionally many spiritual traditional cultural products have been replaced by commercial-modern products. This phenomenon can be studied from the social changes that occured in the Kampung Naga in Tasikmalaya regencies, which on the one hand still maintains its traditional values, on the other hand this traditional village has undergone many changes. This study intends to determine the existence of Sundanese cultural products, as well as products of a national, Indonesian culture in general from the influence of the development of modernism. In addition, by examining the phenomenon of community life in the traditional village of Kampung Naga, it is hoped that the indicators that cause these changes will be known. All objects of this study will be investigated using the qualitative-interpretive methods. This study uses cultural theory, Social Change theory, and semiotic theory as the main reference literature. The data sources used are main (primary) data and secondary data. The main data was obtained directly through interviews with the people of Kampung Naga. Meanwhile, secondary data was obtained from written sources such as: books from previous research, scientific journals, personal documents, photos, statistics, audio and video recordings. Therefore, starting from these initial observations, at least the root cause of social change in Kampung Naga can be described, and its cannot be separated from both internal and external factors behind it, for example: 1) The influence of global modernization, 2) The influence of modernization brought by the people of Kampung Naga who live outside the Traditional Village, 3) The adaptive attitude of the Kampung Naga people living in the Traditional Village. 4) Economic demands and community welfare. These factors are the main source of modernism in Kampung Naga.
\end{abstract}

Keyword: Cultural change, Kampung Naga, Modernism, Traditional Village, Sunda.

\section{Introduction}

Based on Koentjaraningrat (1993:307)

in curtural anthrophology Sundanese

are people who have used the

Sundanese mother tongue for

generations, live in West Java or also

known as Tanah Pasundan or (Sunda
Continent). Sundanese are divided into two types, i.e. who used pure Sundanese Language, for example those who lives in the Priangan area, such as: Ciamis Distric, Tasikmalaya, Garut, Bandung, Sumedang, and Cianjur. These communities are 
contrasted with those who use harsher Sundanese language, seen thriving in northern coastal areas in West Java: Banten, Bogor, Karawang, and Cirebon.

In Raffles notes, the British Governor General who ruled Java in 1811-1816 (2008:5), Sunda region is divided into several districs: Southern and Eastern Batavia division and its suroundings are called the regencies, the term given by Dutch Government to the local ruler who ruled in Preangen. While Central and Southern distric strectch from Batam to Cirebon, Kerawang, Chiasem, Pamanukan, Kandangaur and Dramayu or Indramayu. And southern region consists of Kabupaten Cianjur, Bandung, Sumedang, Limbangan, and Sukapura.

Lombard (2005:29) describes the beauty of Tanah Pasundan different from other socio - cultural groups, i.e. Agrarian Central region of Java and the coastal eastern region of Java. In northern region there is low plateau with about $250 \mathrm{~km}$ length and $50 \mathrm{~km}$ width. In southern region lies impressive Priangan mountains dotted with several volcanoes over $2000 \mathrm{~m}$ high, such as: Salak Mountain (2211 m), Gede Mountain (2958 m), and Pangrango (3022 m).

Looking at the cultural landscape, Tatar Sunda certainly inherited a different, rich culture then other regions. The region not only inherited tangible cultural wealth but also intangible cultural wealth. However, in the midst of an increasingly advanced civilization, now the Sundanese cultural heritage has changed its existence. Many spiritual traditional cultural products have been replaced by commercial, modern cultural products. This phenomenon can be studied from the social changes that occured in Kampung Naga in Tasikmalaya regencies, which on the one hand still maintains its traditional values, on the other this traditional village has undergone many changes. 
As one of the conservation centers for Sundanese, heritage Kampung Naga, like other traditional villages in Nusantara, has ultimately been unable to withstand the growth of civilization. For example, when referring to Suganda's account (2006:44-52) one of the ancestral doctrines that was previously held by the people of Kampung Naga is building code, which must be in accordance with the house cosmology concepts, including: stilt house with a palm fiber roof, built on pedestals, using two types of wall wicker, there is a clear division of rooms (tepas imah, tengah imah, pangkeng, dapur, goah, kolong imah), and built with swales to resist erosion.

But now, along with the modern life influences, the Kampung Naga community's houses have changed not only in form but also in function. For example tepas imah which was originally specifically for private residence, it has been used as a living room for overnight visitors. Likewise all village buildings facilities, including village roads which were originally made of easy to find stone structures, arenow built with purchased concrete materials. According to Jones (2010:33), these functional changes are an indication of modernism, which was preceded by changes in civilization including: 1) capitalism, 2) factory-based mass production, 3) massive urbanization, 4) Western domination, 5) the emergence of scientific secularism.

Starting from initial research conducted by the author, at least it can be seen that the influence of modernity also occurs in people's clothes. For example, the clothes worn by Kampung Naga women who live in traditional houses are symbols of acculturation. Some wear tiung or head coverings made of cloth, then there are those who wear hats, tudung (hoods) or jilbab (headscarves). While the clothes they wear consist of a kebaya in which it is doubled by a Tshirt. This kind of clothing phenomenon reflects the spirit of 
modernism which basically accepts all differences, is free and democratic.

Meanwhile, the clothes worn by teenagers and children reflect more urban lifestyle. This represents a more modern society whose entire social life is based more on commercial culture and consumption. For example, children wearing jeans, colorful tshirts and hats are usually indicatory of big cities. Likewise with food consumption symbolizes modernity. Export drinks like Coca-Cola or Sprite, as well as snacks such as Chiki, Taro, Beng-beng, and others are not foreign to the people of Kampung Naga today. Thern there are also the issues that accompany electronic telecommunications (cellphone), television, and radio.

Based on the initial data collected by the author, at least it can be assumed (initial hypothesis) that a paradoxical life is actually happening to the people of Kampung Naga. On the one hand the older generation is the symbol of the role model, but on the other hand they also use cell phones as a symbol of modernism. Meanwhile the younger generation of Kampung Naga has basically been transformed it into a new city community, where all the clothes they wear are products of industrial culture, consisting of: jeans, trousers and shorts, crocs sandals, colorful T-shirts (as opposed to the Sunda Wiwitan color which is entirely black), using cell phones and consuming soft drinks and premanufactured foods.

Therefore, starting from these initial observations, at least the root cause of social change in Kampung Naga can be described. In the author's opinion, this cannot be separated from both internal and external factors, for example: 1) The influence of global modernization, 2) The influence of modernization brought by the people of Kampung Naga who live outside the traditional village, 3) The adaptive attitude of the Kampung Naga people living in the traditional village. 4) Economic demands and community 
welfare. According to the author, these factors are the main sources of modernism and social change in Kampung Naga.

\section{Method}

This research has a purpose, both specific and more generally conceived.

Broadly speaking, this study aims to determine the existence of Sundanese cultural products, as well as products of national culture in general from the influence of the development of modernism. In addition, by examining the phenomenon of community life in the traditional village of Kampung Naga, it is hoped that the indicators that cause these changes will be revealed. Thus, research on social change through visual studies in the traditional village of Kampung Naga can generally provide inspiration for other researchers. Especially researchers who have a concern for the preservation of local culture within the scope of Sundanese and local culture within the territory of Negara Kesatuan Republik Indonesia (NKRI).

1. To find out the factors behind the occurrence of social change in Kampung Naga, Tasikmalaya Regency.

2. Knowing and understanding the indicators of social change that occurred in Kampung Naga, Tasikmalaya Regency.

3. Understand the concreteness of the symbols of modernity that occurred in Kampung Naga, Tasikmalaya Regency.

4. To understand that the inclusion of modernity symbols has a positive or negative impact on the lives of the Kampung Naga people, Tasikmalaya Regency.

Research on social change in the Kampung Naga community has many benefits, including contribution to both theoretical and practical research, each of which is described below: 


\section{Theoretical Benefits}

1. This research can be used as basic knowledge for the development of fine arts, especially in the field of traditional architecture, as well as social sciences related to local cultural arts.

2. This research is expected to add to the repertoire of methodologies and critical theories regarding the science of traditional architecture, indepndent of Sundanese culture, as well as social sciences related to local cultural arts.

This research can be used for scientific documentation, published in the form of books and journals, which are disseminated to the public.

\section{Practical Benefits}

1. All changes that occur in traditional cultural products in Kampung Naga as well as symbols of modernism can be used as a means or representative media, related to the richness of Sundanese culture in the past that has changed in today's culture.
2. For artists, this research can be used as a reference if they want to explore the study of social change in the local community culture through the visual art paradigm.

3. For education, the results of this research can be used as a reference for the development of education, especially in the field of art aesthetic theacing and the influence of modernism values on the values of the nation's arts and culture.

4. For the general public, the results of this study are very useful as a means of understanding the nature of Indonesian cultural arts, which are not only beautiful but also full of moral teachings.

Research "The Modernity of naga village community: Social change study through visual media analisys" This research uses a research model as described below: First, the research step begins by examining the factors that cause modernization in Kampung Naga. 
Figure 1.

The mechanism of the cultural change process in Kampung Naga

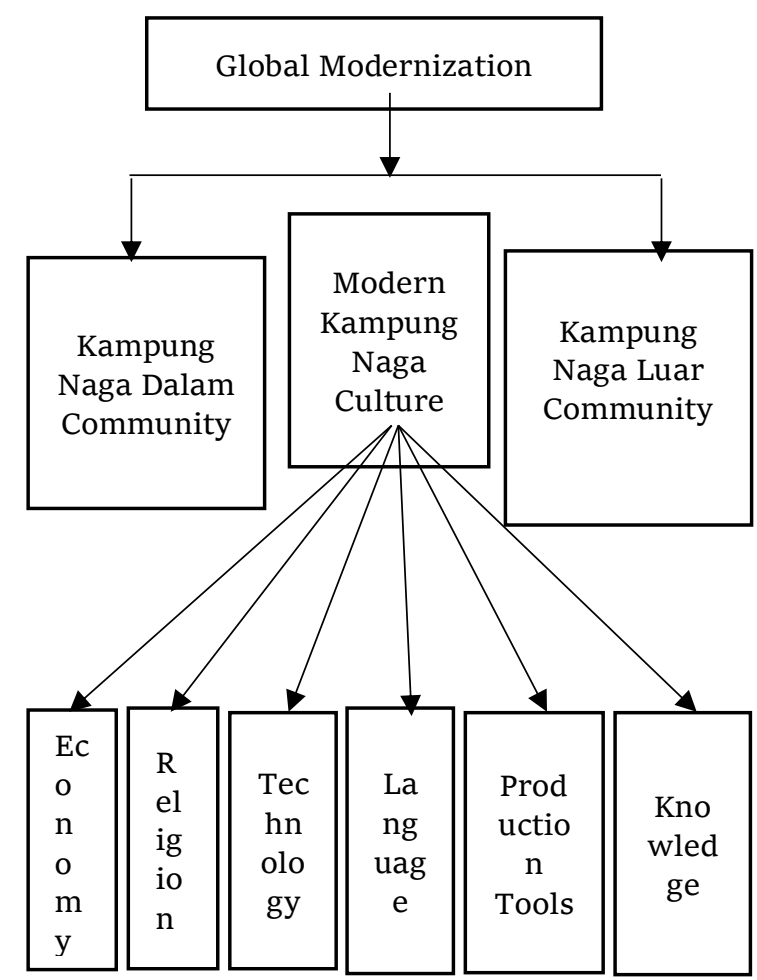

Second, it is continued by studying the relationship between the people of Kampung Naga who live inside and outside the traditional village, which according to the author plays a very important role in creating the influence of modernity in social life in Kampung Naga.

Third, after the variables that affect social life between the people of Kampung Naga who live inside and outside the Traditional Village are analyzed one at a time, then the indicators of modern cultural symbols are described as a form of modernity in Kampung Naga.

In addition to these research steps, an analysis model of cultural acculturation values that occur in Kampung Naga, will also be studied as shown below: Namely, there are two cultural patterns that lead to modernization in Kampung Naga. First is the traditional culture that is still maintained by the people who live in the Traditional Village, and modern culture brought by the people of Kampung Naga who already live outside the Traditional Village. From this mixing of cultures, finally in Kampung Naga an "acculturative" culture was formed, a symbol of democratization, freedom and the individual.

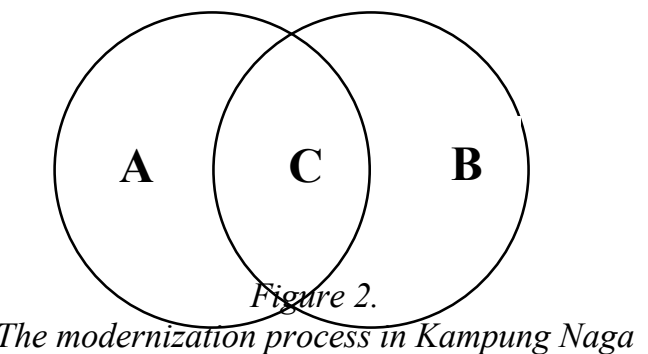


A. The native Kampung Naga community (inside)

B. Kampung Naga people who live outside the village.

C. Modern culture attached to today's Kampung Naga community (a blend of old and new traditions)

In relation to the proposed research, used qualitative-interpretive methods. According to Kutha Ratna (2010:305), starting from the rapid development of social sciences, humanities, especially cultural studies. Therefore, the qualitative method was expanded to be qualitative-interpretive.

\section{Object of Research}

Study object of this research is "The Modernity of naga village community: Social change study through visual media analisys". All objects of this study will be investigated using the field method. However, even so, this research will also use the literature study method as an effort to add needed data needed. Nyoman Kutha Ratna (2010: 196) describes a literature study method that is different from the field method. The literature study method in conducting the research process (data collection) is carried out through places where research results are stored, namely libraries.
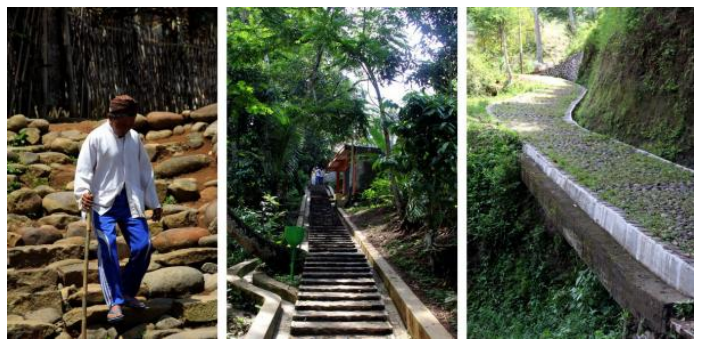

Figure 1.

The path to the Naga village then and now

In this study, a literature review was carried out to explore written sources related to visual analysis of the social changes of the Kampung Naga community, Tasikmalaya Regency. Considering that until now there have been no books or research results that specifically examine "Social Changes in Kampung Naga Community through Visual Media Studies" but the authors still use the results of previous studies as a fairly important reference source. However, to understand the symbols of modernity that occur in the Kampung Naga Community, 
Tasikmalaya Regency certainly cannot ignore other scientific sources. Here are some libray data or literature that will later be used as a reference source in this research.

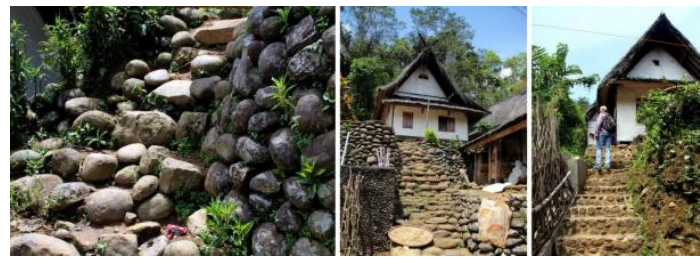

Figure 2.

Changes in natural stone stairs in residential areas

Her Suganda (2006), in a book entitled: “Kampung Naga Mempertahankan Tradisi" inform Kampung Naga culture, in Garut Residence. So this book is very important to be used as a reference sources, because it discussed the data needed in this research. Among other things, it is explained about the relationship between the existence of the Kampung Naga community of Garut Residence with God as the ruler of universe and the cosmological environment. In addition, this book also discusses about the existence of a house which by the people of Kampung Naga is not only interpreted as a "place to live", but more than that it is interpreted as part of the guidance of life taught by their ancestors.
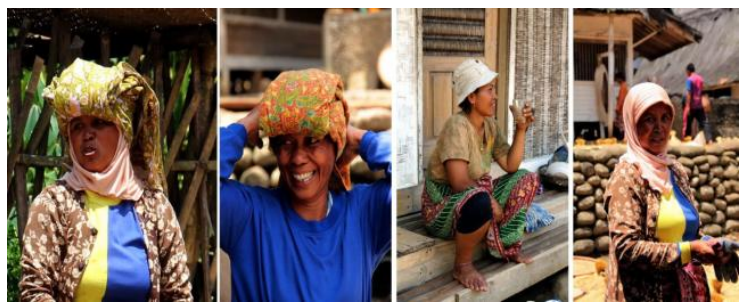

Figure 3.

Women's clothing is a symbol of acculturation

Driyarkara (2006), in his book entitled: “Karya Lengkap Driyarkara: esai-Esai Filsafat Pemikir yang Terlibat Penuh dalam Perjuangan Bangsanya” discusses aesthetics in art, people, and religion. Although the direction of the study is not centered on, but more on philosophy in general. In relation to the Nusantara culture, functionally music is used as a ceremonial medium related to God, the cosmos and between human beings. In Chapter II of this book is about "Aesthetic Experience and Art." It is explained that art is a necessity in human life. Because the existence of art is in line with human life, human existence always goes hand in hand with art, therefore, this book transparently 
explains that art precedes other branches of culture. This can be seen in the culture left behind by prehistoric humans.

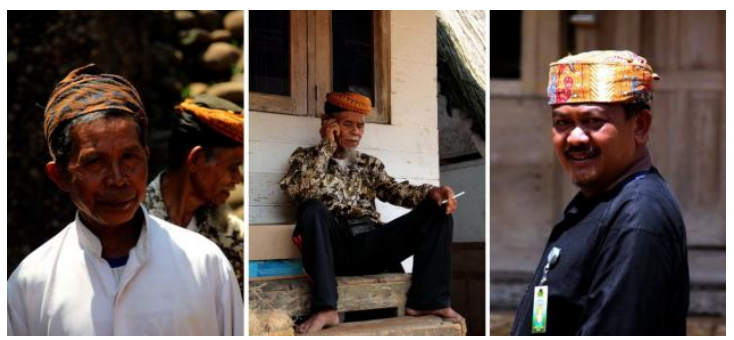

Figure

Traditional clothing and communication tools (cellphone).

Jakob Sumardjo (2006) in "Estetika Paradoks" discusses art in the context of aesthetic philosophy. Especially regarding the phenomenon of art, and its relation to the phenomenon of Indonesian philosophy. As a nation that has its own aesthetic dimension, the aesthetics of art in Indonesia cannot be separated from the national character. According to Jacob Sumardjo, it is different from anthropocentric modern art. Premodern art is in mystical, spiritual, religious culture because it is within the scope of cosmocentric culture. Although in the study of "Estetika Paradoks" Jakob Sumadjo did not specifically discuss traditional architecture, but rather explores traditional art originating from prehistory, this book remains an important resources. Because in programmed research, the aimed goal is a study of traditional architectural aesthetics which cannot be separated from Indonesian philosophy: a principle of thinking and acting of the Indonesian people which cannot be separated from the values of "Divinity and the Universe".

Mudji Sudtrisno and Christ Verhaak (1994), "Estetika Filsafat Keindahan”. This book discusses the nature of philosophy from Western point of view. Starting from the ancient Greek and Roman aesthetics and stretching to the 2oth Century. The author's concern - even though it is not directly related to the aesthetics of Indonesian (Eastern) music - is a presentation on "Beauty", Aesthetics and Artwork of the Three Monotheistic Religions paradigm", as well as "Experiences of Beauty and Reflection on Its 
Philosophy”. This book opens the door to understanding the essence of aesthetics in art. Therefore, Western philosophy is still needed as a mean of analyzing the existence of Eastern art aesthetics. Because theoretically all analytical work in beauty aesthetic cannot be separated from Western theoretical concepts.
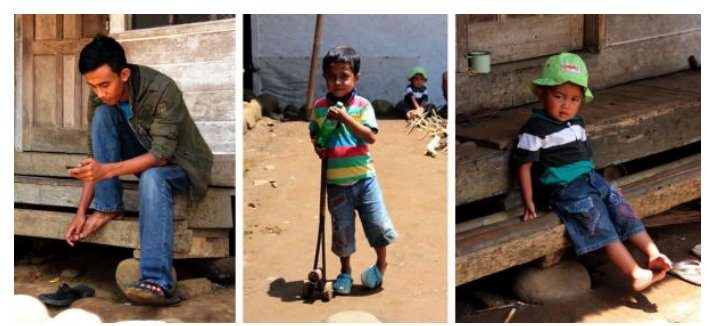

Figure 5

Clothes and drinks for the younger generation of Kampung Naga

Piliang (1999:269), in the book “Hyper-Realitas Kebudayaan" states that a work of art that has a relationship outside of itself, and consists of layers of meaning, so it needs to explored in effort to discover these layers. In this regard, Kristeva distinguishes between two meaningforming practices, namely: 1 . Significance, socially institutionalized and controlled meaning (the sign serves as a reflection of the existing conventions and social codes). 2. Signifiance, subversive and creative meaning. In this case, significance is alimitless creative process. The use of semiotic theory in this research is based on the essence of traditional architecture is as a sign. Methodologically, semiotic analysis is very useful to support structural analysis in order to find the meaning of a creation (art). According to Khuta Ratna, (2004:97) in a book entitled: "Metode Penelitian Kajian Budaya dan Ilmu Sosial Humaniora pada Umumnya" structuralism analysis must be followed by semiotic analysis.

\subsection{Theoretical Basis}

According to the problem formulation, a theoretical basis is needed to deeply understand every phenomenon, with the hope of producing comprehensive new findings. So to fulfill these expectations, the writer uses (1) cultural theory, (2) Social Change Theory and 3) semiotic theory. All of these theories will be used eclectically 
to answer and analyze the problem formulation.

\section{J.W.M Cultural Theory}

J.W.M Bakker SJ said that the characteristics of culture have special attributes namely:

- Exteriorization: Humans through their intellectual powers bring order to nature causing the occurrence of integral products (culture) as things, events or physical objects.

- Communication: the results of human culture (cultural products) are available for use by others. in unity between subjects dialogue by contributing and exchanging ideas so that the results are more perfect and useful.

- Continuity: cultural works continue and and can be a starting point for further development. In the evolution of culture, in turn the subjects functioned as heirs and inheritors. Accepted by the first generation and passed on to future generations. (Bakker, J.W.M., 2000. Cultural Reflections, Kanisius, Yogyakarta).

According to Emile Durkheim (2008: 83), In people's lives, there are two types of social facts, namely: material and non-material. Material social facts, such as architectural styles, forms of technology, products of law and legislation, are relatively easy to understand because they can be observed directly. While behind these social facts often express a greater moral power that is beyond humans. These moral forces are called nonmaterial social facts. Durkheim admits that this non-material social fact has certain limitations because it exists in the individual's mind. But he believes that when people begin to interact perfectly, then the interaction will obey its own laws. Therefore, this cultural theory closely related to the 
object of research, namely traditional architectural art. Which visually traditional architectural forms can be called a social fact, while the philosophical values behind it are nonsocial facts.

\subsubsection{Social Change Theory}

Sztomka, (2010:223) states that agents of change are initially placed outside of human beings and social life. So the agents of change are placed in the supernatural realm, often disguised in the form of an animist power. An incarnate God, a single or a metaphysical God, agents of change are always imagined operating from outside, shape and control the individual or collective and the history of society.

According to Sztomka (2010:224), in modern structural functionalism thought, the source of social change is people who behave deviantly who undermine established social norms.
(Piotr Sztompka, Sosiologi Perubahan Sosial Penerbit Penanda, Jakarta) Jones, (2010: 67), According to Talcot Parson, the increasing industrialization and modern society attests to major changes in the family, According to Talcot Parson, social change is caused by increasing industrialization and modern society proves a major change in the family, because the new industrial economy requires a new form of family to carry out new special Parsons say:

Households organized based on kinship in traditional societies, non-industrial is a place to live and a primary source of agricultural production. In industrial societies, most productive work is carried out in special units such as workshops, an office manned by members of the family household. So, the two sets of roles and collectives are distinguished from their functions. (Parson 1966) 
According to Badudu, (2003) the definition of functionalism begins with the theory that emphasizes the elements in a society or culture are interdependent and become a unitary, which serves for doctrines or teachings that emphasize practical benefits or functional relationships. And second, the linguistic movement which assumes that the phonological, grammatical, and semantic structures are determined by the functions carried out in society, and that language itself has various functions.

\subsubsection{Semiotic Theory}

Semiotic theory is important to use as an analytical tool in "reading" and "interpreting" all the symbols of modernity that occur in the Kampung Naga Traditional Village, Tasikmalaya Regency. According to Ferdinand de Saussure, as explained by Alex Sobur (2004:vii), "Semiotics is the study of the role of signs as part of social life." While Preminger et al, in Djoko Pradopo (2001:71-72) states that semiotics is the knowledge of signs. Its assumes that social and cultural phenomena are signs. Semiotics studies the systems, rules, and conventions that allow these signs to have meaning.

The semiotic theory put forward by Saussure in The New Encyclopedia Britannica, vol 13, 1997, consists of the signifier and the signified. Signifier are sounds, written and read. Signified are mental and physical images. Saussure further said that a signifier without a signified means nothing and therefore not a sign. On the other hand, a signified cannot be conveyed or separated from the signifier. Thus, Saussure states that the signifier and the signified are a unity like two sides of a paper.

While Pierce (in Piliang, 2003:302) distinguish three kinds of signs, i.e. icons, indexes, symbols. An icon is a sign that between the signifier and the signified has similarity or resemblance properties. The index is a 
causal relationship between the signifier and the signified. The symbol is the relationship between the sign and its object determined by a generally accepted rule.

Meanwhile, Piliang (1998:269) states that a work of art that has a relationship with outside the work of art consists of layers of meaning, so it needs to explored to its true meaning. In this regard, Kristeva distinguishes between two meaning-forming practices, namely: 1. Significance, socially institutionalized and controlled meaning (the sign serves as a reflection of the existing conventions and social codes). 2. Signifiance, subversive and creative meaning. In this case, significance is the limitless and unlimited creation process.

According to the title of the study, the research location will be centered in Kampung Naga, Tasikmalaya Regency. In adition to location issues, feared it will take quite a long time, the research will be carried out using a field approach, this will also utilize literature data. And this will be done by actively visiting the Bandung Regional library, ITB, STSI Bandung, or Padjadjaran University, etc.

The research entitled "The Modernity of naga village community: Social change study through visual media analisys" is a study that uses a qualitative-interpretative methods. The data sources used are main (primary) data and secondary data. The main data was obtained directly from informants in the form of words and actions. These data were obtained through interviews with the people of Kampung Naga, Tasikmalaya Regency, for example: humanists, artists, traditional leaders, religious leaders and others. Meanwhile, secondary data was obtained from written sources such as: books from previous research, scientific journals, personal documents, photos, statistics, audio and video recordings. 
All types and sources of data refer to several expert thoughts, among others, Kirk and Miller in Meleong, 2010:157163) explaining that there are two data sources; main (primary) data and secondary data sources. The main data sources in qualitative research are people who are interviewed directly both in words and actions. Secondary data sources include: 1 ). Written data such as books, scientific magazines, archival documents, personal documents, and other official documents. 2). Photo documentation can provide an overview of the historical journey of the people in it, population distribution, geographic location, school system, and others. 3) statistical data can provide an overview of the life of a society.

Saifuddin, (1997:91) explains, primary data is data obtained directly from research subjects as a source of information. While secondary data is obtained through other parties - not directly obtained from the research subject. Meanwhile, according to
Soedarsono (1999:126) data sources are qualitative data sources such as written and oral sources. Written data sources are books, journals, encyclopedias, dictionaries, brochures, newspapers, securities, archives, documents, and manuscripts. And oral sources are information from people who were interviewed as resource persons.

The technique of determining informants is quite important. Koentjaraningrat (1993-89) states that the determination of informants as a data source, uses more considerations of social reality. This means that the informants who will be selected to represent the community are selected by purposive sampling, namely based on certain criteria. According to Usman (2004:47) purposive sampling is used if the informants are specially selected based on research objectives. In addition, there is also a snowballing sampling technique. Sugiyono, (1992:56), states that this technique is 
intended as a way to determine small number of informants (key informants), Then the informant was asked to choose another friend who was considered to know about the problem being studied to be an informant. As stated by Endaswara (2006:115) the information sought, starting from key information (key informants), with the snowball principle, in the sense that informants will develop continuously based on information from key informants. The search for information will be stopped if the data information obtained is no longer new.

Thus, the information determination technique used in this research is purposive sampling and snowballing sampling. Purposive sampling is intended to find data according to certain criteria and research objectives. For example, to find key information, people who are directly related to object of cultural change study in the Kampung Naga Community, Tasikmalaya Residence. From this information, it will develop continuously to find information that comes from key information. Meanwhile, in this context, the key information is all the information provided by the people of Kampung Naga as the culture owner.

To obtain data in the field, research instruments are needed such as audio recorders, video-photo cameras and others. The devices will be used as an analytical tool to facilitate the process carried out by researchers.

According to Arikunto (2002:11), data collection must always be done systematically. In this study, data was collected using observation, interview, recording and literature studies.

Data analysis, Muhajir (1990: 183), is an attempt to systematically find and organize the observation records, interviews and others to increase the researcher's understanding of the researched problem. Furthermore, all the data that has been collected is classified based on researcher needs. 
According to Wuisman, (1996:300), qualitative data analysis is a method of data compaction by developing a taxonomy, descriptive classification system or chronological classification which includes a number of collected information and show a systematic relationship. According to Miles and Heberman in Basrowi and Kelvin (2010: 209), Qualitative data analysis was carried out simultaneously with the data collection process. This analysis technique includes (1) data reduction (2) data presentation (3) conclusion (verification). Data reduction is the process of selecting, centralizing, abstracting, and transforming rough data, which is done from start to finish. Data presentation is done systemically to make it easier to understand in a complete context. Conclusions are drawn by proportional formulations related to logic principle, appointment as research findings, reviewing existing data, grouping the data and the proportions that which has been formulated and then report the complete research results with "new findings".

\section{Conclusion}

Kampung Naga in Tasikmalaya regencies, although in the one hand still maintains its traditional values, on the other hand this traditional village have undergone in many changes. The study intends to determine the existence of Sundanese cultural products, as well as products of national culture in general from the influence of the development of modernism.

In addition, by examining the phenomenon of community life in the traditional village of Kampung Naga, it is hoped that the indicators that cause these changes will be known.

\section{Reference}

Arikunto, Suharsimi. 2002, Prosedur Penelitian: Suatu Pendekatan Praktik, PT. Rineka Cipta, Jakarta.

Badudu, JS. 2006, Kata-Kata Serapan Bahasa Asing Dalam Bahasa Indonesia, Buku Kompas, Jakarta 
Basrowi, 2010 Metode PenelitianKualitatif Mikro, ( $G$ rounded Theory) Fenomenologi, Etnometodologi, Etnografi, Dramaturgi, Interaksi Simbolik, Hermeneutik, Konstruksi Sosial, Analisis Wacana dan Metode Refleksi, Insan Cendekia, Surabaya Chodjim, Achamd, Kosmologi Budaya Sunda, Makalah Seminar: Nilai- Nilai Budaya Sunda Masa lampau dalam Era Globalisasi” Bandung, 15 Juni 2011 Endaswara, Suardi, 2003, Metodologi Penelitian Sastra, Epistemologi, Model, Teori dan Palikasi, Pustaka Widyatama, Yogyakarta

Jones, PIP. 2010, Pengantar Teori- Teori Sosial: Dari Teori Fungsionalisme hingga Post- Modernisme, Yayasan Obor Indonesia, Jakarta

Koentjaraningrat, 1993, Manusia dan Kebudayaan di Indonesia, Penerbit Djambatan, Jakarta

Lombard, Dennys, 2005, Nusa Jawa: Silang Budaya, Kajian Sejarah Terpadu, Jilid 1, Gramedia Pustaka Utama, Jakarta Meleong, Lexy, 2010. Metode Penelitian, Kualitatif, Remaja Rosdakarya, Bandung

Piliang, Yasraf Amir, 1999, Hiper Realitas,Kebudayan, LKIS, Yogyakarta Ratna, Nyoman Kutha, 2010.
Metodologi Penelitian: Kajian Budaya dan Ilmu Sosial Humaniora Umumnya, Pustaka Pelajar, Yogyakarta Ritzer, George (2009), Teori Sosiologi: Dari Teori Sosiologi Klasik Sampai Perkembangan Mutakhir TeoriSosial Postmodern, Kreasi Wacana, Yogyakarta Soemardjo, Jacob, 2006, Estetika Paradoks, Sunan Ambu Press, Bandung Sobur, Alex, 2004, Semiotika Komunikasi, Remaja Rosdakarya, Bandung

Saifuddin, Achmad Fedyani, 2006, Antropologi Kontemporer: Suatu

Pengantar Kritis Mengenai Paradigma, Kencana, Jakarta

Suganda, Her, 2006, Kampung Naga:Mempertahankan Tradisi, Kiblat Buku Utama, Bandung Stamford Raffles, Thomas, The History of Java, Terjemahan Eko Prasetyaningrum Dkk, Penerbit Narasi, Yogyakarya Sztompka, Piotr, 2010 Sosiologi Perubahan Sosial, Penerbit Penanda, Jakarta

Agus setiawan, born in Padalarang, December 07, 1965, earned a Bachelor's Degree (Drs) in the Faculty of Fine Arts and Design, ITB., Instutute Tecnology Bandung in 1991 and a Masters Degree (M.Sn) in the Design Study Program, Bandung Institute of Technology in 2002. I work as a Lecturer in the Visual Communication Design Study Program, Pasundan University and as a teacher. 